\title{
Optimal nitrogen application rates for three intensively-managed hardwood tree species in the southeastern USA
}

\author{
David R. Coyle ${ }^{\mathrm{a}, *}$, Doug P. Aubrey ${ }^{\mathrm{b}}$, Jacek P. Siry ${ }^{\mathrm{a}}$, Roberto R. Volfovicz-Leon ${ }^{\mathrm{c}}$, Mark D. Coleman ${ }^{\mathrm{c}}$ \\ ${ }^{a}$ University of Georgia, D.B. Warnell School of Forestry and Natural Resources, Athens, GA 30602, USA \\ ${ }^{\mathrm{b}}$ Georgia Southern University, Department of Biology, Statesboro, GA 30460, USA \\ ' University of Idaho, Department of Forest, Rangeland, and Fire Sciences, Moscow, ID 83844, USA
}

\section{A R T I C L E I N F O}

\section{Article history:}

Received 13 September 2012

Received in revised form 12 April 2013

Accepted 15 April 2013

\section{Keywords:}

Biomass

Economics

Fertilization

Irrigation

Land Expectation Value

Liquidambar 50 styraciflua

\begin{abstract}
A B S T R A C T
Forest production can be limited by nutrient and water availability, and tree species are expected to respond differently to fertilization and irrigation. Despite these common expectations, multi-species comparisons are rare, especially ones implementing a range of fertilization rates crossed with irrigation. This study compares the response of three forest hardwood species to numerous nitrogen ( $\mathrm{N}$ ) fertilization levels and water availability using a novel non-replicated technique. A range of $\mathrm{N}$ levels was included to determine how $\mathrm{N}$ affected the growth response curve, and statistical procedures for comparing these non-linear response functions are presented. We used growth and yield data to calculate the Land Expectation Value (LEV) for these intensive management treatments, and to determine the optimal growing conditions (accounting for tree productivity and grower expenses). To accomplish these objectives, we used a series of cottonwood, sycamore, and sweetgum plots that received a range of $\mathrm{N}$ fertilization with or without irrigation. Regression is an economical approach to define treatment responses in large-scale experiments, and we recommend $>3$ treatment levels so the response of any single plot does not disproportionally influence the line. The non-replicated plots showed a strong positive $\mathrm{N}$ response below $150 \mathrm{~kg} \mathrm{~N} \mathrm{ha}^{-1} \mathrm{yr}^{-1}$, beyond which little response was observed. However, different amounts of fertilization were required for the greatest biomass accumulation rate in each tree species. Cottonwood and sycamore growth was optimized with less than $150 \mathrm{~kg} \mathrm{~N} \mathrm{ha}^{-1} \mathrm{yr}^{-1}$ while sweetgum growth was optimized with less than $100 \mathrm{~kg} \mathrm{~N} \mathrm{ha}^{-1} \mathrm{yr}^{-1}$. Results from this experiment should be representative of many of the nutrient-poor soils in the Coastal Plain in the southeastern USA. The LEVs were not positive for any treatment $\times$ genotype combination tested when using irrigation or liquid fertilizer, but our analysis showed that several non-irrigated treatments in sycamore and sweetgum did result in positive LEVs when fertilized with granular urea.
\end{abstract}

(c) 2013 Elsevier B.V. All rights reserved.

\section{Introduction}

Nitrogen $(\mathrm{N})$ and water availability can exert a strong influence on forest productivity. Nitrogen is generally considered the most limiting nutrient for tree growth in temperate forest ecosystems (Binkley and Reid, 1984; Fisher and Garbett, 1980; Sword Sayer et al., 2004). Increased $\mathrm{N}$ availability positively influences $\mathrm{N}$ uptake, carbon assimilation, leaf area, and higher productivity rates (Coleman et al., 2006; Meason et al., 2004; Shan et al., 2001; Will et al., 2002, 2006). Water availability is necessary for essential plant growth processes such as photosynthesis and $\mathrm{N}$ uptake (Kramer, 1983). Microbial processes that determine the amount of soil $\mathrm{N}$ available for plant uptake, such as $\mathrm{N}$ mineralization, are

* Corresponding author. Address: University of Georgia, Warnell School of Forestry and Natural Resources, Building 4-434, 180 E. Green Street, Athens, GA 30602, USA. Tel.: +1 706542 2152; fax: +1 7065428356.

E-mail address: drcoyle@uga.edu (D.R. Coyle). positively correlated with soil moisture (Schlesinger and Andrews, 2000). Thus, forest productivity depends not only on N availability, but also on water availability (Coyle and Coleman, 2005; Linder, 1989; Lockaby et al., 1997; Samuelson, 1998).

Forest plantations worldwide employ intensive management practices, including fertilization, irrigation, and competition control to maximize production (Ibell et al., 2010; Jokela et al., 2010; Stape et al., 2006). Intensive forest management can mitigate the effects of suboptimal $\mathrm{N}$ and water availability in low or marginal quality sites and can promote increased productivity in many tree species. While it is not practical to irrigate forest stands in most instances, control of competing vegetation (Zhao et al., 2009) and the application of N fertilizer (Fox et al., 2007; Siry, 2002) can be beneficial, and the use of these silvicultural manipulations has increased extensively.

All crop plants, including trees, can effectively use only a finite amount of N (Brooks and Coulombe, 2009; Ngoze et al., 2008; Smethurst, 2010; Smethurst et al., 2003), and excess is generally 
lost through leaching (Lee and Jose, 2005; Van Miegroet et al., 1994). For example, trees only maximize wood production when an adequate supply of $\mathrm{N}$ is received (Ingestad and Ågren, 1991; Kozlowski and Pallardy, 2002). Therefore, growers are challenged with applying the amount of $\mathrm{N}$ fertilizer that maximizes growth (at the least cost), but not so much as to cause loss through leaching. Identifying this optimal level of fertilization is critical for making sound ecological and financial decisions.

It is difficult to measure the response of forest productivity to a range of management treatments. Large study plots are necessary to eliminate edge effects on tree growth, and the perennial life history of trees requires a commitment of several years before meaningful results can be obtained. Replicated analysis of variance (ANOVA) designs are typical in ecological studies when testing multiple levels of a treatment factor, yet this is difficult in largescale forest research programs. Defining the relationship between tree productivity and several levels of a resource amendment treatment factor is effectively accomplished using non-replicated regression approaches (Borger et al., 2007; Matsuzaki et al., 2009). The regression approach is more powerful and resource efficient than ANOVA designs and is especially well suited for identifying the optimum among a range of treatment levels (Cottingham et al., 2005). The novel approach and analysis we present in this study has broad applicability to intensively-managed forest systems worldwide.

In the southeastern USA, eastern cottonwood (Populus deltoides Bartr.) and American sycamore (Platanus occidentalis L.) respond positively to both fertilization and irrigation (Coyle and Coleman, 2005; Henderson and Jose, 2010; Lockaby et al., 1997), whereas sweetgum (Liquidambar styraciflua L.) responds strongly to fertilization but only weakly to irrigation (Allen et al., 2005; Coyle et al., 2008; Samuelson et al., 2001; Williams and Gresham, 2006). Our objective in the current study was to use a non-replicated regression experimental design to determine the $\mathrm{N}$ fertilization level that would maximize tree productivity and be the most cost effective (i.e., optimal) for these three hardwood tree species under intensive management. We hypothesized that each species would have a different maximum and optimal $\mathrm{N}$ fertilization level, and that irrigation would influence the maximum and optimal $\mathrm{N}$ fertilization level effectively used by each species.

\section{Materials and methods}

The site, plant materials, and experimental design were previously described in detail (Aubrey et al., 2012; Coleman et al., 2004; Coyle and Coleman, 2005; Coyle et al., 2008). A brief description follows.

\subsection{Study area}

The study was conducted at the U.S. Department of Energy Savannah River Site, a National Environmental Research Park, near Aiken, SC, USA $\left(33^{\circ} 23^{\prime} \mathrm{N}, 81^{\circ} 40^{\prime} \mathrm{E}\right)$. This area is part of the Carolina Sandhills Ecoregion, and has primarily Blanton sand soils to a depth of over $1 \mathrm{~m}$ (Rogers, 1990). The region is characterized by warm, humid summers and mild winters, with precipitation spread consistently throughout the year (Coleman et al., 2004). However, because the deep, sandy soils in this area have little water holding capacity, and the climate in the summer can get very warm for extended periods of time, water availability is still a major issue for forest productivity even with relatively consistent precipitation. Prior to study establishment, existing vegetation consisted of longleaf (Pinus palustris Mill.) and loblolly (Pinus taeda L.) pine with an oak (Quercus spp.) understory. The site was cleared in 1999, soil was homogenized to a depth of $30 \mathrm{~cm}$, and an auto- mated irrigation system was installed (Coleman et al., 2004). Pest control measures were used on all treatments, and understory vegetation was controlled completely with herbicides to eliminate plant competition.

\subsection{Plant material}

Cottonwood, sycamore (Westvaco orchard run; Westvaco Corp., Summerville, SC, USA), and sweetgum (half-sib family WV340; Westvaco Corp., Summerville, SC, USA) were evaluated in this study. Two cottonwood clones (ST66: Issaquena Co., MS; and S7C15: Brazos Co., TX; Crown Vantage Corp., Fitler, MS, USA) were included to give a broader genetic representation of the species than is possible with a single clone. Bare-root 1-0 sycamore and sweetgum seedlings were hand planted during February 2000. Dormant cottonwood cuttings were soaked in water for at least $48 \mathrm{~h}$ prior to planting during the second week of April 2000.

\subsection{Experimental design}

Trees were planted at $2.5 \times 3 \mathrm{~m}$ spacing in 0.22 ha plots. Each plot had a central 0.04 ha measurement plot with 54 trees and large end borders planted with additional trees, to accommodate selected destructive sampling.

To define the $\mathrm{N}$ fertilizer response function, eight $\mathrm{N}$ fertilization levels were applied to each species (Table 1). Ecological requirements of the tree species dictated the irrigation treatment assignment in our study. The bottomland hardwoods (cottonwood and sycamore) received irrigation as a primary treatment with eight fertilization levels, as well as three fertilization levels without irrigation. The upland hardwood (sweetgum), which received irrigation as a secondary treatment with three fertilization levels, did not receive irrigation with all fertilization levels as did the cottonwoods and sycamore. Cottonwood and sycamore received higher levels of fertilization than sweetgum to correspond with their greater nutrient demand (Aubrey et al., 2012; Van Miegroet et al., 1994).

Table 1

Fertilization and irrigation treatments applied in this study. Species receiving irrigation as a primary treatment were cottonwoods and sycamore, while sweetgum received irrigation as a secondary treatment.

\begin{tabular}{lcll}
\hline Tree species & $\begin{array}{l}\text { N fertilization } \\
\left(\mathrm{kg} \mathrm{N} \mathrm{ha}^{-1} \mathrm{yr}^{-1}\right)\end{array}$ & Irrigation & $\begin{array}{l}\text { \# plots per } \\
\text { species }\end{array}$ \\
\hline Cottonwood & 0 & No & 3 \\
and sycamore & 0 & Yes & 3 \\
& 30 & Yes & 1 \\
60 & No & 1 \\
& 60 & Yes & 1 \\
90 & Yes & 1 \\
& 120 & No & 3 \\
120 & Yes & 3 \\
& 150 & Yes & 1 \\
& 180 & Yes & 1 \\
& 210 & Yes & 1 \\
& 0 & No & 3 \\
0 & Yes & 3 \\
& 20 & No & 1 \\
& 40 & No & 1 \\
& 60 & No & 1 \\
60 & Yes & 1 \\
80 & No & 1 \\
& 100 & No & 1 \\
120 & No & 3 \\
120 & Yes & 3 \\
& 140 & No & 1 \\
& & & \\
& & & \\
& & &
\end{tabular}


Fertilization and irrigation treatments were independent, applied using drip irrigation lines (i.e., fertigation), and split among 26 weekly applications from the first of April through the end of October each year. Fertilizer application supplied $5 \mathrm{~mm}$ of water per week. Non-fertilized plots also received $5 \mathrm{~mm}$ water per week ( $130 \mathrm{~mm}$ annually) to maintain experimental consistency. Drip irrigation treatments were designed to apply up to $5 \mathrm{~mm}$ of water per day to meet 30-year average daily evaporative demand for the site (Coleman et al., 2004). Daily proportions of the maximum daily demand in $1 \mathrm{~mm}$ increments were based on potential evapotransporation measured with an on-site weather station.

Fertilizer application rates increased during stand establishment to correspond with demand made by growing trees. This "ramp-up" method of fertilizer application has been shown to benefit tree growth and reduce $\mathrm{N}$ leaching and subsequent groundwater contamination (Van Miegroet et al., 1994). Cottonwood and sycamore received one-third of the target fertilization rate in year one, two-thirds of the target rate in year two, and the full target rate thereafter. Sweetgum received one-third the target fertilization rate in years one and two, two-thirds of its target rate in years three and four, and the full target rate thereafter. Other macro- and micro-nutrients were applied in balance with $\mathrm{N}$ (Aubrey et al., 2012; Coleman et al., 2004; Coyle and Coleman, 2005; Coyle et al., 2008).

\subsection{Growth and biomass determination}

Height and diameter at breast height (DBH, $1.37 \mathrm{~m})$ were recorded annually during winter dormancy on every live tree in the measurement plot. The range of diameters within each treatment was used to select trees for destructive harvests. Trees were randomly chosen within each of five diameter strata to represent the entire range of diameters present within a treatment. Destructive harvests occurred in two stages. First, trees in the replicated experiment were destructively harvested in 2006. Within a species, we harvested one or two trees per plot, for a total of five trees per treatment. Aboveground biomass was separated into branch and stem components for each tree. Branch and stem fresh mass was recorded in the field, and representative subsamples were removed to determine water mass. All tissues were dried to constant mass at $60{ }^{\circ} \mathrm{C}$ prior to weighing. Woody belowground biomass was measured by excavating the stump and lateral roots attached to the stump (hereafter referred to as stump) using a mechanical tree spade (model TS34C, Bobcat Co., West Fargo, ND, USA). A cone of $1 \mathrm{~m}$ diameter and $0.69 \mathrm{~m}$ deep was removed, for a total volume of $0.18 \mathrm{~m}^{3}$. The stump and lateral roots present within this cone were excavated and washed. Fresh stump and lateral root mass was determined, and representative subsamples were removed for moisture content measurement. The second stage of the destructive harvests occurred in December 2007, and occurred in all non-replicated plots. One tree was selected from each of three diameter strata in each plot and above- and belowground biomass was harvested in the same manner as described for the replicated plots.

\subsection{Biomass calculations and statistical analysis}

We estimated branch, stem, and stump biomass fractions $(y)$ from measurements of individual tree diameter using

$y=a x^{b}+\varepsilon$

where $x$ is DBH (cm), $a$ and $b$ are regression parameters, and $\varepsilon$ is a random normally distributed additive error term with zero mean and constant variance (Coyle and Coleman, 2005; Coyle et al., 2008; Parresol, 1999). Parameter values for these allometric biomass equations were determined for each species by treatment combination using branch, stem, and stump biomass of the harvested trees. Parameter values were then applied to estimate branch, stem, and stump biomass for all live trees in each plot as a function of DBH. Nonlinear regressions of biomass components from the replicated plots relied on biomass data from multiple years (and were predicted for 2007 based on data from 2000 to 2006), whereas non-replicated plots relied only on biomass data from the 2007 harvest. Total biomass was calculated as the sum of branch, stem, and stump biomass. The model parameters were estimated using PROC NLIN in SAS (Version 9.1.3, SAS Inc., Cary, NC, USA); all subsequent analyses were also performed using SAS.

Quadratic regression was used to model the response of biomass to $\mathrm{N}$ fertilization and to determine the amount of $\mathrm{N}$ fertilization required to maximize stem and total biomass production for each species with and without irrigation. We modeled the data using the quadratic equation

$Y=b_{0}+b_{1} \mathrm{~N}+b_{2} \mathrm{~N}^{2}+\varepsilon$

where $Y$ is stem or total biomass $\left(\mathrm{Mg} \mathrm{ha}^{-1}\right), \mathrm{N}$ is nitrogen fertilization rate $\left(\mathrm{kg} \mathrm{ha}^{-1}\right.$ year $\left.^{-1}\right), b_{0}, b_{1}$, and $b_{2}$ are regression parameters, and $\varepsilon$ is a random normally distributed error term with zero mean and constant variance. Each parameter in Eq. (2) has a physical connotation: $b_{0}$, the intercept, represents the amount of biomass obtained when no $\mathrm{N}$ fertilizer is applied $(\mathrm{N}=0) ; b_{1}$ represents the growth response when no $\mathrm{N}$ fertilizer is applied, i.e., intercept of the first derivative, Eq. (3), and $b_{2}$ describes how the growth response changes (second derivative of the function $Y$ described in Eq. (2), $\left.\frac{d^{2} Y}{d N^{2}}=d b_{2}\right)$. The level of $\mathrm{N}$ fertilizer $\left(\mathrm{N}=\mathrm{N}_{O P T}\right)$ that results in a maximum biomass can be determined by setting the derivative of Eq. (2) equal to zero and solving for $\mathrm{N}$ :

$\frac{d Y}{d \mathrm{~N}}=b_{1}+2 b_{2} \mathrm{~N}=0$

$\mathrm{N}=\mathrm{N}_{\mathrm{OPT}}=\frac{-b_{1}}{2 b_{2}}$

The point estimate for $\mathrm{N}_{O P T}$ does not offer any evidence on the accuracy or reliability of this quantity. Confidence intervals for $\mathrm{N}_{O P T}$ that results in a maximum biomass, and the corresponding maximum mean biomass response ( $Y$ at $\mathrm{N}=\mathrm{N}_{O P T}$ ) for each species with and without irrigation were computed.

Confidence intervals for the value of the optima were obtained by applying the Delta method. The Delta method is based on using Taylor series expansions for estimating variances, standard errors, and covariances of functions of parameter estimators. A detailed explanation of this technique can be found in Casella and Berger (2001). From Eq. (4) observe that the optimum level of $\mathrm{N}$ fertilizer is estimated from a function (ratio) of the parameter estimates $\left(\widehat{\mathrm{N}_{O P T}}=\frac{-\widehat{b_{1}}}{2 b_{2}}\right.$, where $\widehat{\mathrm{N}_{O P T}}, \widehat{b_{1}}$, and $\widehat{b_{2}}$ denote sample estimates of the true and unknown population parameters $\mathrm{N}_{O P T}, b_{1}$ and $b_{2}$, respectively). An application of the Delta method to Eq. (4) shows that the variance of the estimated optimum can be written as:

$\operatorname{Var}\left(\widehat{\mathrm{N}_{O P T}}=\frac{-\widehat{b_{1}}}{\widehat{2 b_{2}}}\right)=\frac{1}{\widehat{b_{2}^{4}}}\left[\widehat{\sigma_{1}^{2}} \widehat{b_{2}^{2}}-2 \widehat{b_{1}} \widehat{b_{2}} \widehat{\sigma_{12}}+\widehat{\sigma_{2}^{2}} \widehat{b_{1}^{2}}\right]$

where $\widehat{\sigma_{1}^{2}}$ is the variance of $\widehat{b_{1}}, \widehat{\sigma_{2}^{2}}$ is the variance of $\widehat{b_{2}}$, and $\widehat{\sigma_{12}}$ is the covariance between $\widehat{b_{1}}$ and $\widehat{b_{2}}$ (Kuha and Temple, 2003). It follows that the $100(1-\alpha) \%$ confidence limits $(C L)$ for the optimum level of $\mathrm{N}$ fertilizer can be expressed as: 


$$
\begin{aligned}
C L\left(\widehat{\mathrm{N}_{O P T}}=\frac{-\widehat{b_{1}}}{\widehat{2 b_{2}}}\right)= & \frac{\widehat{-b_{1}}}{\widehat{2 b_{2}}} \pm z \alpha / 2 \\
& \times \sqrt{\frac{1}{\widehat{b_{2}^{4}}}\left[\widehat{\sigma_{1}^{2}} \widehat{b_{2}^{2}}-2 \widehat{b_{1}} \widehat{b_{2}} \widehat{\sigma_{12}}+\widehat{\sigma_{2}^{2}} \widehat{b_{1}^{2}}\right]}
\end{aligned}
$$

where $z$ is the appropriate percentile of the standard normal distribution.

Confidence intervals for the estimation of the mean response biomass at the optimum level of nitrogen fertilizer ( $\widehat{Y}$ at $\mathrm{N}=\widehat{\mathrm{N}_{O P T}}$ ) for each species with and without irrigation were directly computed using PROG REG in SAS.

The fitted curves for each species with and without irrigation were used to predict biomass for the varying levels of nitrogen fertilizer. The resulting quadratic regression curves fitted for each species with and without irrigation were compared to identify any significant difference using the Kolmogorov-Smirnov test (Conover, 1999). The principle of the test is to rank all the observations from two populations, e.g., $X_{1}$ and $X_{2}$; establish the empirical cumulative distribution functions $F_{1}\left(X_{1}\right)$ and $F_{2}\left(X_{2}\right)$; and compute the maximum vertical distance between the two empirical distribution functions: $T=\max \left|F_{1}\left(X_{1}\right)-F_{2}\left(X_{2}\right)\right|$. The maximum difference is then compared with a critical value from a Kolmogorov-Smirnov table at a given level of significance $\alpha$ and sample sizes of both populations. If the Kolmogorov-Smirnov statistic $T$ is smaller than the critical value, then the null hypothesis is accepted, indicating that no significant difference between the two curves exists (Conover, 1999).

Model diagnostics were carried out in the final regression models to check whether the distributional assumptions for the residuals (constancy of error variance and normality of error terms) were satisfied.

\subsection{Financial analysis}

Potential financial returns were estimated with discounted cash flow methods (Lutz, 2001). The experimental management scenarios and their outcomes were evaluated by calculating the Land Expectation Value (LEV, also termed Bare Land Value, Soil Expectation Value, or Faustmann formula [Brazee, 2001]), which represents the sum of discounted net returns (benefits less costs) of perpetual timber rotations (Straka and Bullard, 1996). Stated differently, it represents the maximum price an investor would pay per unit area of bare land, if the land were to be managed according to the evaluated management scenario. This approach provides an indication of the value of the land in forest production as it assumes that land value is equal to the stream of discounted net benefits (net present value, NPV) of an infinite series of rotations. The NPV for a single rotation can be defined as:

$$
\begin{aligned}
\mathrm{NPV} & =\sum_{t=0}^{\mathrm{N}} \frac{\text { Benefits }_{t}-\text { Costs }_{t}}{(1+r)^{t}}=\sum_{t=0}^{\mathrm{N}} \frac{B_{t}-C_{t}}{(1+r)^{t}} \\
& =\sum_{t=0}^{\mathrm{N}} \frac{B_{t}}{(1+r)^{t}}-\sum_{t=0}^{\mathrm{N}} \frac{C_{t}}{(1+r)^{t}}
\end{aligned}
$$

where $r=$ discount rate and $t=$ year. Once the NPV for a single production cycle is assessed, the LEV can be calculated as:

$\mathrm{LEV}=\mathrm{NPV}+\frac{\mathrm{NPV}}{(1+r)^{t}-1}$

where $t=$ rotation age, and other terms are defined as above.

We calculated potential financial returns based on commercially-available methods of plantation management using annual discount rates of $3 \%, 5 \%$ and $7 \%$ in real terms (excluding inflation). Biomass price used in this analysis was assumed to be $\$ 50$ per oven dry metric ton (odmt) (average value of $\$ 67$ odmt $^{-1}$ for non-conifer chips, - 25\% for transportation costs; Wood Resource Quarterly, 2012). Site preparation, cuttings, and planting amounted to $\$ 600 \mathrm{ha}^{-1}$ (Kline and Coleman, 2010). Herbicides, insecticides, and acaricides were applied for the first 4 years of the rotation at the cost of $\$ 100 \mathrm{ha}^{-1} \mathrm{yr}^{-1}$ (Kline and Coleman, 2010); our cost includes supplies and labor.

With regard to fertilizer applications, we evaluated two possible scenarios. The first scenario relied on applying liquid $\mathrm{N}$ solutions $(30 \% \mathrm{~N})$ while the other used granular urea $(46 \% \mathrm{~N})$ applied with a fixed wing aircraft. A drip irrigation system was used in both scenarios. The total annual irrigation cost, including rental fees, electricity and other operational expenses, amounted to $\$ 292 \mathrm{ha}^{-1}$ (Gallagher et al., 2006) with urea and was $\$ 50$ higher $\left(\$ 342 \mathrm{ha}^{-1}\right)$ for liquid nitrogen solutions applications due to increased operational costs.

Fertilizer prices were provided by the USDA National Agricultural Statistics Service (http://www.ers.usda.gov/data-products/ fertilizer-use-and-price.aspx). Based on 30\% N solution prices from 2000 to 2012 and $\$ 50$ per ton delivery fee, we calculated the price per applied kg N at $\$ 0.65$ (low), $\$ 1.10$ (average), and $\$ 1.66$ (high). To calculate costs using aerially applied urea, we examined 2000-2012 fertilizer prices, added $\$ 200$ per ton for delivery and application, and converted these costs into \$ per applied $\mathrm{kg} \mathrm{N}$ so we can match application rates from liquid fertilizer scenarios. Using these assumptions, we obtained urea costs of $\$ 0.94, \$ 1.39$, and $\$ 1.81$. The fertilizer delivery costs were provided by local firms specializing in forest applications.

\section{Results}

\subsection{Stand and growth characteristics}

After 8 years, both fertilization and irrigation elicited positive growth responses compared to untreated controls (Fig. 1). Table 2 includes stand characteristics for treated plots including mean tree $\mathrm{DBH}$, height, and basal area. There are consistent patterns that appear for each of the species. For each of the stand characteristics, growth generally increases with increasing fertilization and typically reaches a maximum at some intermediate $\mathrm{N}$ rate. The magnitude of stand characteristics for irrigated treatments are typically greater that non-irrigated treatments.

\subsection{Species-specific biomass responses to fertilization and irrigation}

We used quadratic regression curves of final biomass versus $\mathrm{N}$ application rate [Eq. (2)] to compare among species and treatments. Stem and total biomass were well correlated with $\mathrm{N}$ fertilization ( $R^{2}$ varied from 0.617 to 0.989 ) for all species and irrigation levels (Table 3, Figs. 2 and 3). Biomass consistently increased to a maximum at intermediate $\mathrm{N}$ fertilizer rates for each species by irrigation treatment combination except for irrigated S7C15 and nonirrigated sycamore. For these exceptions, and based on the trajectory of the growth response curve, maximum biomass accumulation likely occurred beyond the highest applied $\mathrm{N}$ rate (Table 4). Non-irrigated plots showed better quadratic fit among species $\left(0.833 \leqslant R^{2} \leqslant 0.989\right)$ than irrigated plots $\left(0.617 \leqslant R^{2} \leqslant 0.844\right)$ largely due to the fact that most non-irrigated curves had only one intermediate and unreplicated $\mathrm{N}$ application rate located near the estimated optimum, which exerted considerable influence. Irrigated plots consistently produced larger values of stem and total biomass when no $\mathrm{N}$ fertilizer was applied (predicted with intercept $b_{0}$ ) than the non-irrigated counterparts (Table 3). In absence of $\mathrm{N}$ fertilization, irrigation increased biomass predictions by less than $20 \%$ in ST66, nearly $40 \%$ in sweetgum, and over 100\% in S7C15 


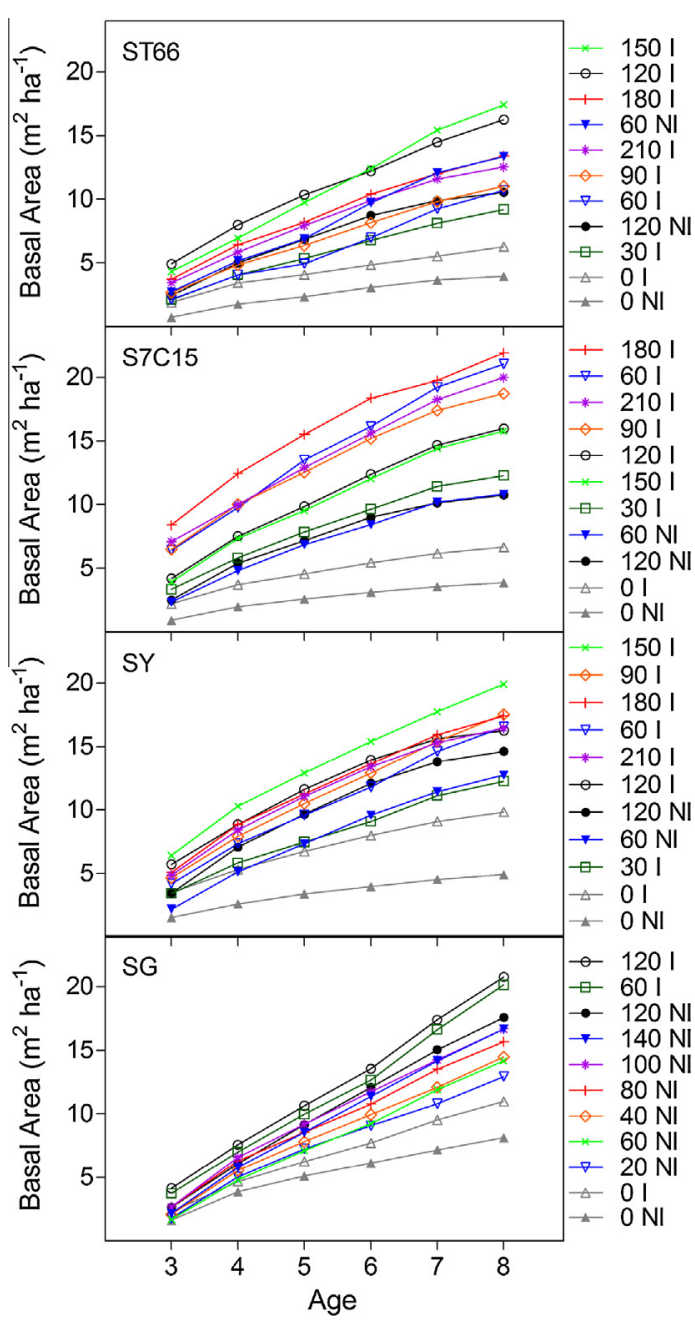

Fig. 1. Basal area of cottonwood ST66 (ST66) and S7C15 (S7C15), sycamore (SY) and sweetgum (SG) in response to rate of $\mathrm{N}$ fertilization ( $\left.\mathrm{F}, \mathrm{kg} \mathrm{N} \mathrm{ha}^{-1} \mathrm{yr}^{-1}\right)$ and plus (I) or minus irrigation (NI). Individual data points represent basal area values from a single non-replicated plot, except for $\mathrm{N}$ application rates of 0 and $120 \mathrm{~kg} \mathrm{~N} \mathrm{ha}^{-1}$ $\mathrm{yr}^{-1}$ where individual data points represent the mean of biomass from three replicate plots. Basal area in years 1 and 2 is not shown, as all trees had not reached $\mathrm{dbh}$. For each graph, the treatments in the legend are listed in the order of the final basal area value for that tree type.

and sycamore. In total these results suggest that irrigation had a positive effect on biomass accumulation; however, sycamore was the only species that showed a significant increase in the absence of $\mathrm{N}$.

Differences among species and between irrigation treatments were evaluated for the optimal amounts of $\mathrm{N}$ fertilization required to maximize biomass, and the maximum biomass that can be attained at optimum N. Simultaneous confidence intervals for these values are shown in Table 4 for each species with and without irrigation. Irrigation had moderate effect on the optimal $\mathrm{N}$ application rate with a significant difference $(P<0.10)$ observed only for ST66 (Table 4). The relatively low optimal N value for non-irrigated ST66 was significantly different than the optima for sycamore and sweetgum, but not for S7C15, despite this latter type having the greatest $\mathrm{N}$ optima observed. The single intermediate point for non-irrigated ST66 appeared to have considerable influence on the optimum for that species, and the large scatter among points for S7C15 together with the optimal point being estimated beyond the range of the $\mathrm{N}$ application rates used to fit the regression model resulted in the largest confidence interval of any species. The opti-
Table 2

Stand characteristics of two intensively-managed cottonwood clones, sycamore, and sweetgum after eight growing seasons (2000-2007) in South Carolina, USA.

\begin{tabular}{|c|c|c|c|c|}
\hline Species & $\begin{array}{l}\mathrm{N} \text { fertilization rate } \\
\left(\mathrm{kg} \mathrm{ha}^{-1} \mathrm{yr}^{-1}\right)\end{array}$ & $\begin{array}{l}\text { Dbh } \\
(\mathrm{cm})\end{array}$ & $\begin{array}{l}\text { Height } \\
(\mathrm{m})\end{array}$ & $\begin{array}{l}\text { Basal area } \\
\left(\mathrm{m}^{2} \mathrm{ha}^{-1}\right)\end{array}$ \\
\hline \multirow{8}{*}{$\begin{array}{l}\text { Cottonwood ST66 } \\
\text { irrigated }\end{array}$} & 0 & 7.4 & 7.5 & 6.3 \\
\hline & 30 & 9.3 & 10.6 & 9.2 \\
\hline & 60 & 10.1 & 11.7 & 10.7 \\
\hline & 90 & 10.4 & 11.5 & 11.1 \\
\hline & 120 & 11.9 & 13.6 & 16.3 \\
\hline & 150 & 12.3 & 14.1 & 17.4 \\
\hline & 180 & 11.4 & 12.7 & 13.4 \\
\hline & 210 & 11.1 & 12.6 & 12.5 \\
\hline \multirow[t]{3}{*}{ Non-irrigated } & 0 & 5.7 & 6.1 & 4.0 \\
\hline & 60 & 10.3 & 11.7 & 13.4 \\
\hline & 120 & 9.8 & 11.2 & 10.6 \\
\hline \multirow{8}{*}{$\begin{array}{l}\text { Cottonwood } \\
\text { S7C15 } \\
\text { irrigated }\end{array}$} & 0 & 7.6 & 8.0 & 6.7 \\
\hline & 30 & 10.2 & 12.8 & 12.3 \\
\hline & 60 & 13.4 & 16.2 & 21.1 \\
\hline & 90 & 12.9 & 15.5 & 18.7 \\
\hline & 120 & 11.7 & 13.1 & 16.0 \\
\hline & 150 & 12.1 & 13.9 & 15.8 \\
\hline & 180 & 13.5 & 15.6 & 22.0 \\
\hline & 210 & 13.2 & 15.2 & 20.0 \\
\hline \multirow[t]{3}{*}{ Non-irrigated } & 0 & 5.9 & 6.4 & 3.9 \\
\hline & 60 & 9.5 & 10.3 & 10.8 \\
\hline & 120 & 10.0 & 11.5 & 10.8 \\
\hline \multirow{8}{*}{$\begin{array}{l}\text { Sycamore } \\
\text { irrigated }\end{array}$} & 0 & 9.6 & 10.9 & 9.9 \\
\hline & 30 & 10.7 & 12.4 & 12.3 \\
\hline & 60 & 12.3 & 14.5 & 16.6 \\
\hline & 90 & 12.6 & 15.2 & 17.6 \\
\hline & 120 & 12.9 & 15.5 & 16.3 \\
\hline & 150 & 13.5 & 15.4 & 19.9 \\
\hline & 180 & 12.6 & 14.3 & 17.4 \\
\hline & 210 & 12.4 & 13.7 & 16.5 \\
\hline \multirow[t]{3}{*}{ Non-irrigated } & 0 & 6.7 & 7.5 & 4.9 \\
\hline & 60 & 10.8 & 12.3 & 12.8 \\
\hline & 120 & 11.8 & 13.9 & 14.6 \\
\hline \multirow{3}{*}{$\begin{array}{l}\text { Sweetgum } \\
\text { irrigated }\end{array}$} & 0 & 9.9 & 9.4 & 11.0 \\
\hline & 60 & 13.7 & 13.5 & 20.1 \\
\hline & 120 & 13.7 & 12.7 & 20.8 \\
\hline \multirow[t]{8}{*}{ Non-irrigated } & 0 & 8.7 & 8.2 & 8.2 \\
\hline & 20 & 11.2 & 10.5 & 13.0 \\
\hline & 40 & 11.6 & 10.5 & 14.5 \\
\hline & 60 & 11.5 & 11.0 & 14.2 \\
\hline & 80 & 12.1 & 11.4 & 15.7 \\
\hline & 100 & 12.5 & 11.2 & 16.7 \\
\hline & 120 & 12.8 & 11.8 & 17.6 \\
\hline & 140 & 12.6 & 11.2 & 16.7 \\
\hline
\end{tabular}

mal N points for S7C15 for both total and stem biomass are too distant from the range of feasible $\mathrm{N}$ values to yield meaningful confidence limits in the context of this study (Table 4, Figs. 2 and 3).

Irrigation significantly increased the values of maximum total biomass obtained at the optimal $\mathrm{N}$ application rates by $94 \%$ in S7C15, $25 \%$ in sycamore, and $37 \%$ sweetgum (Table 4 ). Though not statistically significant, stem biomass did vary between the two irrigation levels, with the irrigated plots having larger values of maximum biomass for all genotypes. Sweetgum had the largest values of maximum stem and total biomass (56 and $93 \mathrm{Mg} \mathrm{ha}^{-1}$, respectively) at optimum $\mathrm{N}$ application rates, followed by sycamore, cottonwood S7C15, and cottonwood ST66. 
Table 3

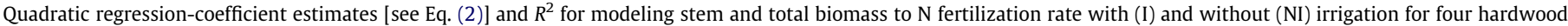
tree types. Standard errors are shown in parentheses.

\begin{tabular}{|c|c|c|c|c|c|c|c|c|c|}
\hline \multirow[t]{2}{*}{ Species } & \multirow[t]{2}{*}{ Irrigation } & \multicolumn{4}{|c|}{ Stem Biomass } & \multicolumn{4}{|c|}{ Total Biomass } \\
\hline & & $\overline{R^{2}}$ & $b_{0}$ & $b_{1}$ & $b_{2}$ & $\overline{R^{2}}$ & $b_{0}$ & $b_{1}$ & $b_{2}$ \\
\hline \multirow[t]{2}{*}{$\begin{array}{l}\text { Cottonwood } \\
\text { ST66 }\end{array}$} & I & 0.638 & $\begin{array}{l}7.093 \\
(4.942)\end{array}$ & $\begin{array}{l}0.4058 \\
(0.121)\end{array}$ & $\begin{array}{c}-0.0015 \\
(0.0010)\end{array}$ & 0.682 & $\begin{array}{c}12.440 \\
(5.522)\end{array}$ & $\begin{array}{l}0.4894 \\
(0.135)\end{array}$ & $\begin{array}{l}-0.0018 \\
(0.00069)\end{array}$ \\
\hline & $\mathrm{NI}$ & 0.837 & $\begin{array}{l}6.224 \\
(2.619)\end{array}$ & $\begin{array}{l}0.6326 \\
(0.166)\end{array}$ & $\begin{array}{c}-0.0045 \\
(0.0014)\end{array}$ & 0.8325 & $\begin{array}{l}10.542 \\
(3.473)\end{array}$ & $\begin{array}{l}0.7814 \\
(0.220)\end{array}$ & $\begin{array}{c}-0.0054 \\
(0.0018)\end{array}$ \\
\hline \multirow[t]{2}{*}{$\begin{array}{l}\text { Cottonwood } \\
\text { S7C15 }\end{array}$} & I & 0.6167 & $\begin{array}{l}15.669 \\
(9.621)\end{array}$ & $\begin{array}{l}0.2963 \\
(0.214)\end{array}$ & $\begin{array}{c}-0.00063 \\
(0.00098)\end{array}$ & 0.652 & $\begin{array}{l}22.706 \\
(12.037)\end{array}$ & $\begin{array}{l}0.4245 \\
(0.268)\end{array}$ & $\begin{array}{c}-0.0010 \\
(0.0012)\end{array}$ \\
\hline & $\mathrm{NI}$ & 0.973 & $\begin{array}{l}6.058 \\
(0.954)\end{array}$ & $\begin{array}{l}0.3535 \\
(0.0605)\end{array}$ & $\begin{array}{l}-0.0019 \\
(0.00049)\end{array}$ & 0.973 & $\begin{array}{l}10.631 \\
(1.361)\end{array}$ & $\begin{array}{l}0.5270 \\
(0.08636)\end{array}$ & $\begin{array}{l}-0.0029 \\
(0.00071)\end{array}$ \\
\hline \multirow[t]{2}{*}{ Sycamore } & I & 0.628 & $\begin{array}{l}27.585 \\
(4.632)\end{array}$ & $\begin{array}{l}0.3296 \\
(0.1134)\end{array}$ & $\begin{array}{l}-0.0011 \\
(0.00058)\end{array}$ & 0.643 & $\begin{array}{l}40.961 \\
(6.07)\end{array}$ & $\begin{array}{l}0.4116 \\
(0.148)\end{array}$ & $\begin{array}{c}-0.0012 \\
(0.00076)\end{array}$ \\
\hline & $\mathrm{NI}$ & 0.989 & $\begin{array}{l}10.240 \\
(1.1866)\end{array}$ & $\begin{array}{l}0.4637 \\
(0.0753)\end{array}$ & $\begin{array}{l}-0.0016 \\
(0.00062)\end{array}$ & 0.987 & $\begin{array}{l}17.540 \\
(1.710)\end{array}$ & $\begin{array}{l}0.7128 \\
(0.109)\end{array}$ & $\begin{array}{l}-0.0031 \\
(0.00089)\end{array}$ \\
\hline \multirow[t]{2}{*}{ Sweetgum } & I & 0.844 & $\begin{array}{l}20.236 \\
(4.9415)\end{array}$ & $\begin{array}{l}0.8341 \\
(0.3136)\end{array}$ & $\begin{array}{c}-0.0049 \\
(0.0026)\end{array}$ & 0.827 & $\begin{array}{l}39.782 \\
(8.600)\end{array}$ & $\begin{array}{l}1.0870 \\
(0.546)\end{array}$ & $\begin{array}{c}-0.00553 \\
(0.0045)\end{array}$ \\
\hline & $\mathrm{NI}$ & 0.929 & $\begin{array}{l}14.298 \\
(1.6351)\end{array}$ & $\begin{array}{l}0.4181 \\
(0.06742)\end{array}$ & $\begin{array}{l}-0.0019 \\
(0.00050)\end{array}$ & 0.940 & $\begin{array}{l}28.702 \\
(2.501)\end{array}$ & $\begin{array}{l}0.710 \\
(0.103)\end{array}$ & $\begin{array}{l}-0.0032 \\
(0.00077)\end{array}$ \\
\hline
\end{tabular}

Both visual graphical comparison and the Kolmogorov-Smirnov test indicate that irrigation affected the response to $\mathrm{N}$ fertilization. An overlaid graph of the irrigated and non-irrigated quadratic plots by genotype suggested that the curves deviated from each other (Figs. 2 and 3). This was corroborated by the Kolmogorov-Smirnov test across all genotypes, which showed that irrigated and non-irrigated curves significantly deviated from each other for both stem and total biomass (all $P<0.02$ ). Residual plots of all models (not shown) did not show major systematic deviations confirming that the quadratic regression models described the data well.

\subsection{Financial analysis}

There is no practical scenario where a landowner would install an irrigation system and not provide irrigation; therefore, values for liquid fertilizer treatments under non-irrigated conditions were not calculated. Under irrigated conditions, there were no fertilization scenarios for any species in our study that generated positive LEVs (Table 5). Likewise, using granular broadcast fertilizer we found no scenarios that generated positive LEVs for either cottonwood clone (Table 6). Non-irrigated sycamore receiving fertilization rates of 60 and $120 \mathrm{~kg} \mathrm{~N} \mathrm{ha}^{-1} \mathrm{yr}^{-1}$ did achieve positive LEVs ranging from $\$ 122$ to $\$ 1539 \mathrm{ha}^{-1}$ (Table 6). Sweetgum growth resulted in many positive LEVs ranging from $\$ 82$ to $\$ 2713 \mathrm{ha}^{-1}$; these values were largely in the non-irrigated plots receiving fertilization (Table 6).

As costs increased with management intensity, production did not (Figs. 2 and 3). Therefore, when comparing LEV values with fertilizer application rates, it appears that the most positive financial returns were, in most cases, achieved with moderate fertilization rates ranging from 30 to $90 \mathrm{~kg} \mathrm{~N} \mathrm{ha}^{-1} \mathrm{yr}^{-1}$. Irrigation represented a substantial additional cost, and our analysis indicates that using irrigation was not fiscally beneficial with growth rates reported in this study.

\subsection{Biomass changes relative to optimal $N$ and $L E V$}

Increases in $\mathrm{N}$ application rates were generally not proportional to increases in biomass accumulation or LEV. In fact, most species had the greatest LEV on silvicultural treatments well below the $\mathrm{N}$ application rate required for maximum growth. For instance, the highest sycamore LEVs occurred in non-irrigated treatments receiving 60 or $120 \mathrm{~kg} \mathrm{~N} \mathrm{ha}^{-1} \mathrm{yr}^{-1}$, while the greatest growth occurred in irrigated treatments receiving $150-210 \mathrm{~kg} \mathrm{~N} \mathrm{ha}^{-1} \mathrm{yr}^{-1}$ (Tables 2 and 6). Likewise, sweetgum receiving fertilization at a rate of $60 \mathrm{~kg} \mathrm{~N} \mathrm{ha}^{-1} \mathrm{yr}^{-1}$ had a higher LEV than that receiving $120 \mathrm{~kg} \mathrm{~N} \mathrm{ha}^{-1} \mathrm{yr}^{-1}$, even though volume growth was $3.4 \mathrm{odmt}$ greater in the higher fertilization treatment (Tables 2 and 6).

\section{Discussion}

\subsection{Tree growth}

The use of multiple treatment levels allowed us to evaluate tree genotypes over a range of independent $\mathrm{N}$ fertilization and irrigation levels, and we were able to identify some treatment combinations that resulted in favorable growth rates. The recorded maximum biomass accumulation rates in our study, while experimental, suggest that certain hardwood species native to the southeastern USA have the potential to be economically profitable components of intensively-managed forest plantations. We believe our growth results would be comparable to other areas in the Coastal Plain of the southeastern USA, as soils in this region are commonly nutrient deficient (Fox et al., 2007). However, this growth potential may only be realized by using optimal fertilization regimes.

Cottonwood clone S7C15 accumulated stem biomass at a rate of over $6.3 \mathrm{Mg} \mathrm{ha}^{-1} \mathrm{yr}^{-1}$, and these production ranges are comparable to published growth rates. Hybrid poplar clones in Eastern Canada obtained stem growth rates between 1.3 and $11.6 \mathrm{Mg} \mathrm{ha}^{-1} \mathrm{yr}^{-1}$ (Fortier et al., 2010). Populus spp. stem biomass in the Pacific Northwest, USA ranged from 7.6 to $17.1 \mathrm{Mg} \mathrm{ha}^{-1} \mathrm{yr}^{-1}$ (DeBell et al., 1996); values reported were green weights, and assuming roughly $50 \%$ wood water content, these values are similar to those recorded in our study. Aboveground (stem + branch) biomass of the fastest growing Populus selections in the midwestern USA ranged from 8.0 to $24.5 \mathrm{Mg} \mathrm{ha}^{-1} \mathrm{yr}^{-1}$ after at least 8 growing seasons (Zalesny et al., 2009), although these values assume 100\% stocking. Populus spp. aboveground biomass in Colorado, USA ranged from 6.8 to $12.0 \mathrm{Mg} \mathrm{ha}^{-1} \mathrm{yr}^{-1}$ (Pearson et al., 2010), and 4.2 to 

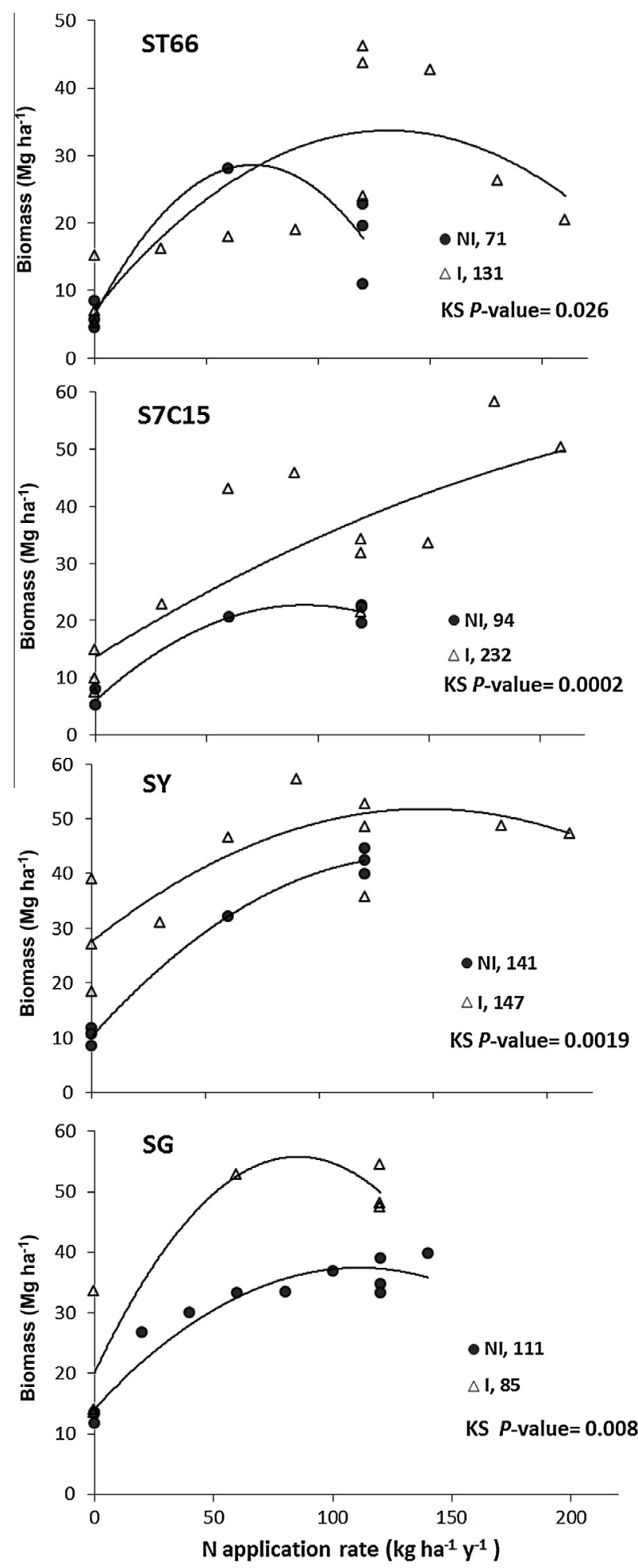

Fig. 2. Stem biomass yield as a function of $\mathrm{N}$ application rate for irrigated (open triangle; I) and non-irrigated (closed circle; NI) cottonwood ST66 and S7C15, sycamore (SY), and sweetgum (SG). Individual data points represent biomass values from a single plot. The number following I or NI designates the optimal $\mathrm{N}$ application rate as determined by Eq. (4). Growth curves from irrigated and nonirrigated plots significantly deviated from each other for all genotypes (all $P<0.05$; Kolmogorov-Smirnov test).

12.9 $\mathrm{Mg} \mathrm{ha}^{-1} \mathrm{yr}^{-1}$ in Florida, USA (Henderson and Jose, 2010). However, the study by Fortier et al. (2010) was not fertilized, and Pearson et al. (2010) fertilized at only one moderate level (112 $\mathrm{kg} \mathrm{N} \mathrm{ha}^{-1} \mathrm{yr}^{-1}$ ), suggesting that increased fertilization may
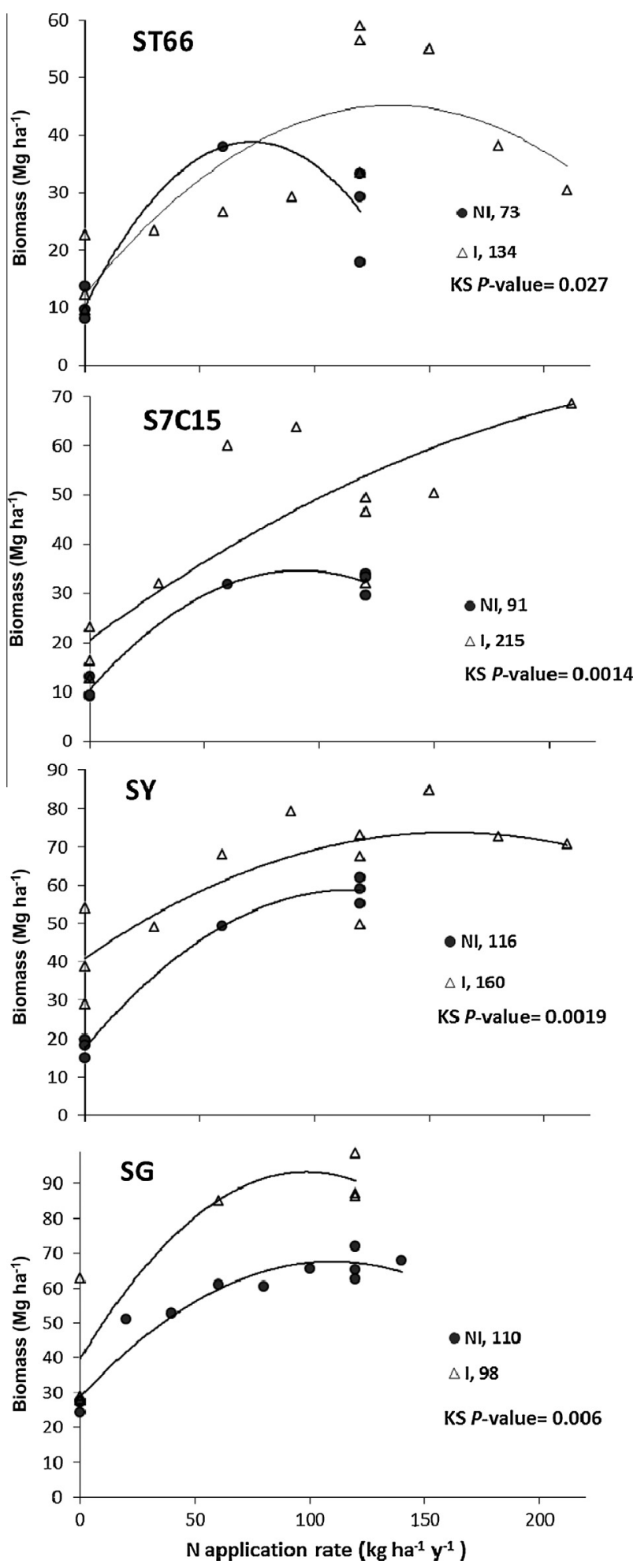

Fig. 3. Total biomass yield as a function of $\mathrm{N}$ application rate for irrigated (open triangle; I) and non-irrigated (closed circle; NI) cottonwood ST66 and S7C15, sycamore (SY), and sweetgum (SG). Individual data points represent biomass values from a single plot. The number following I or NI designates the optimal $\mathrm{N}$ application rate as determined by Eq. (4). Growth curves from irrigated and nonirrigated plots significantly deviated from each other for all genotypes (all $P<0.05$; Kolmogorov-Smirnov test).

have improved yield, but probably not LEV. Henderson and Jose (2010) recorded the greatest growth rates in irrigated only or low fertilization (56 $\mathrm{kg} \mathrm{N} \mathrm{ha}^{-1} \mathrm{yr}^{-1}$ ) treatments. 
Table 4

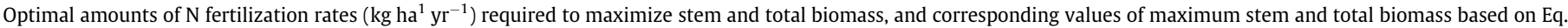

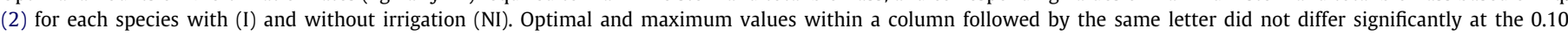
probability level. Simultaneous confidence intervals were constructed with an overall confidence level of $90 \%$.

\begin{tabular}{|c|c|c|c|c|c|c|c|c|}
\hline \multirow[t]{2}{*}{ Biomass type } & \multirow[t]{2}{*}{ Species } & \multirow[t]{2}{*}{ Irrigation } & \multicolumn{3}{|c|}{ Optimum $\mathrm{N}$ rate $\left(\mathrm{kg} \mathrm{ha}^{-1} \mathrm{y}^{-1}\right)$} & \multicolumn{3}{|c|}{ Maximum Biomass $\left(\mathrm{Mg} \mathrm{ha}^{-1}\right)$} \\
\hline & & & Optimum N & Lower $90 \% \mathrm{CL}$ & Upper $90 \%$ L & Maximum Biomass & Lower $90 \% \mathrm{CL}$ & Upper $90 \%$ CL \\
\hline \multirow[t]{8}{*}{ Stem } & Cottonwood ST66 & I & $131 \mathrm{a}$ & 99 & 163 & $34 \mathrm{bc}$ & 27 & 41 \\
\hline & & $\mathrm{NI}$ & $71 \mathrm{~b}$ & 63 & 79 & $29 \mathrm{ab}$ & 19 & 38 \\
\hline & Cottonwood S7C15 & I & $232 \mathrm{ab}$ & 0 & 562 & 50 abcd & 22 & 78 \\
\hline & & $\mathrm{NI}$ & $94 \mathrm{ab}$ & 79 & 110 & $23 a$ & 20 & 25 \\
\hline & Sycamore & I & $147 \mathrm{a}$ & 94 & 200 & $52 \mathrm{~d}$ & 46 & 58 \\
\hline & & $\mathrm{NI}$ & $141 \mathrm{a}$ & 91 & 192 & $43 \mathrm{bcd}$ & 38 & 49 \\
\hline & Sweetgum & I & $85 \mathrm{ab}$ & 61 & 109 & $56 \mathrm{~cd}$ & 40 & 71 \\
\hline & & $\mathrm{NI}$ & $111 \mathrm{a}$ & 89 & 132 & $37 \mathrm{bc}$ & 35 & 40 \\
\hline \multirow[t]{8}{*}{ Total } & Cottonwood ST66 & I & $134 \mathrm{a}$ & 102 & 166 & $45 \mathrm{ab}$ & 38 & 53 \\
\hline & & $\mathrm{NI}$ & $73 \mathrm{~b}$ & 63 & 82 & $39 a b$ & 27 & 51 \\
\hline & Cottonwood S7C15 & I & $215 \mathrm{ab}$ & 0 & 449 & $68 \mathrm{bc}$ & 42 & 95 \\
\hline & & NI & $91 \mathrm{ab}$ & 78 & 105 & 35 a & 31 & 39 \\
\hline & Sycamore & I & $160 \mathrm{a}$ & 88 & 231 & $74 \mathrm{df}$ & 65 & 82 \\
\hline & & $\mathrm{NI}$ & $116 \mathrm{a}$ & 89 & 143 & $59 \mathrm{c}$ & 55 & 62 \\
\hline & Sweetgum & I & $98 \mathrm{ab}$ & 45 & 151 & $93 \mathrm{f}$ & 72 & 115 \\
\hline & & $\mathrm{NI}$ & $110 \mathrm{a}$ & 91 & 129 & $68 \mathrm{~d}$ & 64 & 71 \\
\hline
\end{tabular}

The largest irrigated sycamore accrued over $9.3 \mathrm{Mg} \mathrm{ha}^{-1} \mathrm{yr}^{-1}$ of stem biomass in our study, similar to that of previously reported growth rates of sycamore in the southeastern USA, where growth ranged from 2.4 to $14.5 \mathrm{Mg} \mathrm{ha}^{-1} \mathrm{yr}^{-1}$ (see Coyle and Coleman, 2005; Davis and Trettin, 2006; Henderson and Jose, 2010). Few studies follow sycamore beyond 6 years of growth due to the species' propensity for high mortality (Geyer, 2006; Henderson and Jose, 2010).

Maximum sweetgum growth with irrigation in this study exceeded that of several published studies from the southeastern US. Stem production between 1.5 and $6.6 \mathrm{Mg} \mathrm{ha}^{-1} \mathrm{yr}^{-1}$ has been reported in 6- to 9-year-old sweetgum in the southeastern US (see Coyle et al., 2008; Davis and Trettin, 2006). Stem production of over $7.5 \mathrm{Mg} \mathrm{ha}^{-1} \mathrm{yr}^{-1}$ was observed in our study, a rate more than $30 \%$ greater than previously reported in similarly aged trees.

\subsection{Management implications}

Growth of each tree species was maximized at a different N fertilization level, suggesting that individual species evaluations are necessary to maximize production while minimizing inputs. Few studies examine tree growth at multiple levels of fertilization, and to our knowledge this is the first study to use a regression approach to assess optimum $\mathrm{N}$ application rates and the corresponding maximum yields. Our study suggests that irrigation positively impacted the maximum total biomass values attained and the corresponding optimum $\mathrm{N}$ application rates for the three species. Trees maximize stemwood growth under conditions of optimal N availability (Ingestad and Ågren, 1991). Therefore, forest plantation managers should strive to apply appropriate amounts of $\mathrm{N}$ that will maximize growth while keeping operating costs low. Nitrogen fertilizer is often a major expense to forest plantation managers, and efficient use of $\mathrm{N}$ fertilization is financially necessary. Trees appeared to capture nearly all of the fertilizer applied in this study when accounting for belowground accumulation and fine root turnover (Aubrey et al., 2012), yet other studies have shown that $\mathrm{N}$ fertilizer applied in excess of what trees can uptake is lost through leaching (Van Miegroet et al., 1994; Lee and Jose, 2005), resulting in financial losses and ecological repercussions. With already slim profit margins and a strong push for ecological sustainability in forest plantation management, one way to improve the overall productivity, profitability, and quality of forest plantations is to apply $\mathrm{N}$ fertilization at optimal rates that maximize growth but minimize losses through leaching. Optimal rates are likely species- and silvicultural treatment-specific, and regression studies such as these would be useful for growers worldwide.

All investment schemes were evaluated based on the commercially-relevant prices and an 8 year rotation. Irrigation proved to be simply too expensive to justify its use under current growth rates, and to that end liquid fertilization was also unprofitable. Beyond irrigation, the costs most likely to change are the price of fertilizer or the value of wood. Fertilizer prices are tied to the energy markets: oil prices are likely to stay high; however, natural gas prices will stay low for the foreseeable future. The value of wood may go up, and if so, would likely change some of the negative LEVs into positives. Further, it may be that an 8-year rotation is not the optimal one, and that financial results can be improved by managing trees on longer or shorter rotations. For instance, the growth curves for both cottonwoods and sycamore, while still increasing, are not doing so at rates as great as sweetgum (Fig. 1). This suggests that we harvested the cottonwoods and sycamore at the most profitable time, and that sweetgum might benefit from a longer rotation. One way to improve LEVs for these species (and all other commercially-grown crops) is to improve productivity. We have included only a set of common management costs - additional costs may alter the eventual fiscal return. In conclusion, our analysis simply indicates that positive financial returns associated with intensive management of native hardwood species would only be possible if productivity were increased, or the value of woody biomass material increased. To that end, more work is needed to evaluate and identify the best management schemes to determine if hardwood biomass can be financially viable in the southeastern USA.

\subsection{Regression design and biometrics}

Defining the relationship between tree productivity and several levels of a resource amendment treatment factor is effectively accomplished using non-replicated regression approaches (Borger 
Table 5

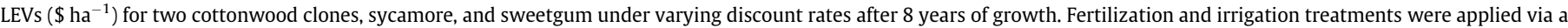

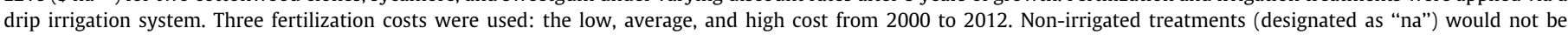
fertilized with liquid fertilizer.

\begin{tabular}{|c|c|c|c|c|c|c|c|c|c|c|}
\hline \multirow[t]{2}{*}{ Species } & \multirow{2}{*}{$\begin{array}{l}\mathrm{N} \text { fertilization rate } \\
\left(\mathrm{kg} \mathrm{ha}^{-1} \mathrm{yr}^{-1}\right)\end{array}$} & \multicolumn{3}{|c|}{ 3\% Discount rate } & \multicolumn{3}{|c|}{$5 \%$ Discount rate } & \multicolumn{3}{|c|}{ 7\% Discount rate } \\
\hline & & $\begin{array}{l}\text { Low cost } \\
\$ 0.65\end{array}$ & $\begin{array}{l}\text { Ave. cost } \\
\$ 1.11\end{array}$ & $\begin{array}{l}\text { High cost } \\
\$ 1.66\end{array}$ & $\begin{array}{l}\text { Low cost } \\
\$ 0.65\end{array}$ & $\begin{array}{l}\text { Ave. cost } \\
\$ 1.11\end{array}$ & $\begin{array}{l}\text { High cost } \\
\$ 1.66\end{array}$ & $\begin{array}{l}\text { Low cost } \\
\$ 0.65\end{array}$ & $\begin{array}{l}\text { Ave. cost } \\
\$ 1.11\end{array}$ & $\begin{array}{l}\text { High cost } \\
\$ 1.66\end{array}$ \\
\hline \multirow{8}{*}{$\begin{array}{l}\text { Cottonwood ST66 } \\
\text { irrigated }\end{array}$} & 0 & -13783 & -13783 & -13783 & -8547 & -8547 & -8547 & -6303 & -6303 & -6303 \\
\hline & 30 & -12984 & -13372 & -13855 & -8121 & -8352 & -8639 & -6033 & -6197 & -6400 \\
\hline & 60 & -13081 & -13858 & -14825 & -8195 & -8657 & -9231 & -6097 & -6424 & -6830 \\
\hline & 90 & -13345 & -14510 & -15960 & -8362 & -9055 & -9917 & -6223 & -6713 & -7322 \\
\hline & 120 & -10040 & -11594 & -13527 & -6536 & -7460 & -8609 & -5023 & -5676 & -6489 \\
\hline & 150 & -9959 & -11901 & -14317 & -6511 & -7665 & -9101 & -5020 & -5837 & -6853 \\
\hline & 180 & -13587 & -15917 & -18817 & -8558 & -9943 & -11666 & -6395 & -7375 & -8594 \\
\hline & 210 & -15368 & -18086 & -21469 & -9573 & -11189 & -13200 & -7084 & -8228 & -9650 \\
\hline \multirow[t]{3}{*}{ Non-irrigated } & 0 & na & na & na & na & na & na & na & na & na \\
\hline & 60 & na & na & na & na & na & na & na & na & na \\
\hline & 120 & na & na & na & na & na & na & na & na & na \\
\hline \multirow{8}{*}{$\begin{array}{l}\text { Cottonwood S7C15 } \\
\text { irrigated }\end{array}$} & 0 & -13337 & -13337 & -13337 & -8298 & -8298 & -8298 & -6137 & -6137 & -6137 \\
\hline & 30 & -11472 & -11860 & -12343 & -7276 & -7507 & -7794 & -5472 & -5635 & -5838 \\
\hline & 60 & -7471 & -8248 & -9214 & -5061 & -5522 & -6097 & -4013 & -4340 & -4746 \\
\hline & 90 & -7276 & -8441 & -9891 & -4972 & -5664 & -6526 & -3968 & -4458 & -5068 \\
\hline & 120 & -11378 & -12931 & -14865 & -7284 & -8207 & -9356 & -5520 & -6173 & -6986 \\
\hline & 150 & -10874 & -12815 & -15232 & -7022 & -8176 & -9612 & -5360 & -6176 & -7193 \\
\hline & 180 & -6058 & -8388 & -11288 & -4351 & -5736 & -7460 & -3598 & -4578 & -5798 \\
\hline & 210 & -8832 & -11551 & -14934 & -5921 & -7537 & -9548 & -4656 & -5800 & -7222 \\
\hline \multirow[t]{3}{*}{ Non-irrigated } & 0 & na & na & na & na & na & na & na & na & na \\
\hline & 60 & na & na & na & na & na & na & na & na & na \\
\hline & 120 & na & na & na & na & na & na & na & na & na \\
\hline \multirow[t]{8}{*}{ Sycamore irrigated } & 0 & -9708 & -9708 & -9708 & -6270 & -6270 & -6270 & -4789 & -4789 & -4789 \\
\hline & 30 & -9319 & -9707 & -10190 & -6073 & -6304 & -6591 & -4672 & -4835 & -5039 \\
\hline & 60 & -6901 & -7678 & -8644 & -4742 & -5204 & -5778 & -3802 & -4128 & -4535 \\
\hline & 90 & -5247 & -6412 & -7862 & -3838 & -4530 & -5392 & -3215 & -3705 & -4314 \\
\hline & 120 & -7973 & -9526 & -11459 & -5381 & -6304 & -7453 & -4255 & -4908 & -5721 \\
\hline & 150 & -5374 & -7316 & -9732 & -3949 & -5103 & -6539 & -3317 & -4133 & -5150 \\
\hline & 180 & -8246 & -10576 & -13476 & -5574 & -6959 & -8682 & -4411 & -5391 & -6611 \\
\hline & 210 & -9227 & -11945 & -15328 & -6142 & -7757 & -9768 & -4803 & -5946 & -7369 \\
\hline \multirow[t]{3}{*}{ Non-irrigated } & 0 & na & na & na & na & na & na & na & na & na \\
\hline & 60 & na & na & na & na & na & na & na & na & na \\
\hline & 120 & na & na & na & na & na & na & na & na & na \\
\hline \multirow[t]{3}{*}{ Sweetgum irrigated } & 0 & -10646 & -10646 & -10646 & -6795 & -6795 & -6795 & -5138 & -5138 & -5138 \\
\hline & 60 & -4466 & -5125 & -5946 & -3372 & -3761 & -4246 & -2884 & -3158 & -3498 \\
\hline & 120 & -4068 & -5387 & -7028 & -3180 & -3959 & -4928 & -2778 & -3325 & -4007 \\
\hline \multirow[t]{8}{*}{ Non-irrigated } & 0 & na & na & na & na & na & na & na & na & na \\
\hline & 20 & na & na & na & na & na & na & na & na & na \\
\hline & 40 & na & na & na & na & na & na & na & na & na \\
\hline & 60 & na & na & na & na & na & na & na & na & na \\
\hline & 80 & na & na & na & na & na & na & na & na & na \\
\hline & 100 & na & na & na & na & na & na & na & na & na \\
\hline & 120 & na & na & na & na & na & na & na & na & na \\
\hline & 140 & na & na & na & na & na & na & na & na & na \\
\hline
\end{tabular}

et al., 2007; Matsuzaki et al., 2009). While several unreplicated regression approaches have been tested in agronomic settings (Aravindhakshan et al., 2011; Blumenthal et al., 2003; Kimetu et al., 2004; Vogel et al., 2002), we believe this regression study design is unique for forestry studies. Our results show that it is possible to develop non-linear growth response curves to $\mathrm{N}$ fertilization rates using a novel regression approach. A quadratic model is frequently fitted in regression to infer the existence of optimal points in a relationship. After the optimal points are found it is necessary to establish if those are meaningful values in the context of our problem, i.e. determine if the optimal points fall within the range of fertilizer application rates used in the study. A quadratic regression equation will always yield an optimum point, however the optimum may be too distant from the range of feasible values to be meaningful. Since the estimates of the optimal points are random variables (ratios between the quadratic regression parameters), the question of feasibility becomes a probability question that can be answered by the construction of confidence intervals for the location of the optimal values, and the width of the confidence intervals provides information regarding the uncertainty of the true and unknown optimal values (Hirschberg and Lye, 2004). The comparison between regression parameters and the evaluation of optimal $\mathrm{N}$ rates demonstrate that it is possible to develop uncertainty estimates for meaningful regression statistics. The response curves so developed represent mean yield response to $\mathrm{N}$ fertilization that can be used to guide management prescriptions that optimize decision making in fertilization management. From an ecological perspective, an impor- 
Table 6

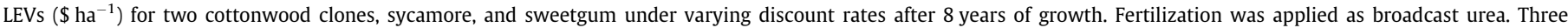

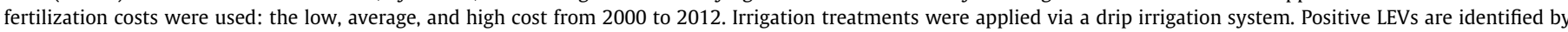
bold print.

\begin{tabular}{|c|c|c|c|c|c|c|c|c|c|c|}
\hline \multirow[t]{2}{*}{ Species } & \multirow{2}{*}{$\begin{array}{l}\mathrm{N} \text { fertilization rate } \\
\left(\mathrm{kg} \mathrm{ha}^{-1} \mathrm{yr}^{-1}\right)\end{array}$} & \multicolumn{3}{|c|}{ 3\% Discount rate } & \multicolumn{3}{|c|}{$5 \%$ Discount rate } & \multicolumn{3}{|c|}{ 7\% Discount rate } \\
\hline & & $\begin{array}{l}\text { Low cost } \\
\$ 0.94\end{array}$ & $\begin{array}{l}\text { Ave. cost } \\
\$ 1.39\end{array}$ & $\begin{array}{l}\text { High cost } \\
\$ 1.81\end{array}$ & $\begin{array}{l}\text { Low cost } \\
\$ 0.94\end{array}$ & $\begin{array}{l}\text { Ave. cost } \\
\$ 1.39\end{array}$ & $\begin{array}{l}\text { High cost } \\
\$ 1.81\end{array}$ & $\begin{array}{l}\text { Low cost } \\
\$ 0.94\end{array}$ & $\begin{array}{l}\text { Ave. cost } \\
\$ 1.39\end{array}$ & $\begin{array}{l}\text { High cost } \\
\$ 1.81\end{array}$ \\
\hline \multirow{8}{*}{$\begin{array}{l}\text { Cottonwood ST66 } \\
\text { irrigated }\end{array}$} & 0 & -12116 & -12116 & -12116 & -7547 & -7547 & -7547 & -5588 & -5588 & -5588 \\
\hline & 30 & -11567 & -11956 & -12318 & -7269 & -7500 & -7716 & -5424 & -5588 & -5740 \\
\hline & 60 & -11915 & -12692 & -13417 & -7493 & -7954 & -8385 & -5593 & -5920 & -6225 \\
\hline & 90 & -12429 & -13594 & -14681 & -7809 & -8501 & -9148 & -5824 & -6314 & -6771 \\
\hline & 120 & -9375 & -10928 & -12378 & -6131 & -7055 & -7916 & -4729 & -5383 & -5993 \\
\hline & 150 & -9544 & -11486 & -13298 & -6255 & -7409 & -8486 & -4832 & -5649 & -6411 \\
\hline & 180 & -13422 & -15752 & -17927 & -8450 & -9835 & -11128 & -6312 & -7292 & -8207 \\
\hline & 210 & -15453 & -18172 & -20709 & -9614 & -11230 & -12738 & -7107 & -8250 & -9317 \\
\hline \multirow[t]{3}{*}{ Non-irrigated } & 0 & -3024 & -3024 & -3024 & -2066 & -2066 & -2066 & -1655 & -1655 & -1655 \\
\hline & 60 & -178 & -955 & -1680 & -533 & -995 & -1426 & -678 & -1004 & -1309 \\
\hline & 120 & -3726 & -5279 & -6729 & -2573 & -3497 & -4358 & -2075 & -2728 & -3338 \\
\hline \multirow{8}{*}{$\begin{array}{l}\text { Cottonwood S7C15 } \\
\text { irrigated }\end{array}$} & 0 & -11671 & -11671 & -11671 & -7298 & -7298 & -7298 & -5423 & -5423 & -5423 \\
\hline & 30 & -10055 & -10444 & -10806 & -6425 & -6655 & -6871 & -4863 & -5026 & -5178 \\
\hline & 60 & -6305 & -7082 & -7807 & -4358 & -4820 & -5251 & -3509 & -3836 & -4141 \\
\hline & 90 & -6360 & -7525 & -8613 & -4418 & -5110 & -5757 & -3570 & -4060 & -4517 \\
\hline & 120 & -10712 & -12266 & -13716 & -6879 & -7802 & -8664 & -5226 & -5880 & -6489 \\
\hline & 150 & -10458 & -12400 & -14212 & -6766 & -7920 & -8997 & -5172 & -5988 & -6751 \\
\hline & 180 & -5893 & -8223 & -10398 & -4244 & -5629 & -6921 & -3516 & -4496 & -5410 \\
\hline & 210 & -8917 & -11636 & -14173 & -5962 & -7578 & -9086 & -4679 & -5822 & -6889 \\
\hline \multirow[t]{3}{*}{ Non-irrigated } & 0 & -2967 & -2967 & -2967 & -2034 & -2034 & -2034 & -1634 & -1634 & -1634 \\
\hline & 60 & -1561 & -2337 & -3062 & -1306 & -1767 & -2198 & -1191 & -1518 & -1823 \\
\hline & 120 & -2705 & -4259 & -5709 & -2003 & -2927 & -3788 & -1696 & -2349 & -2959 \\
\hline \multirow[t]{8}{*}{ Sycamore irrigated } & 0 & -8041 & -8041 & -8041 & -5270 & -5270 & -5270 & -4075 & -4075 & -4075 \\
\hline & 30 & -7902 & -8290 & -8653 & -5222 & -5452 & -5668 & -4063 & -4226 & -4379 \\
\hline & 60 & -5735 & -6512 & -7237 & -4040 & -4501 & -4932 & -3298 & -3624 & -3929 \\
\hline & 90 & -4331 & -5496 & -6584 & -3284 & -3977 & -4623 & -2816 & -3306 & -3763 \\
\hline & 120 & -4959 & -6900 & -8713 & -3693 & -4847 & -5924 & -3129 & -3945 & -4708 \\
\hline & 150 & -8081 & -10411 & -12586 & -5466 & -6851 & -8144 & -4329 & -5308 & -6223 \\
\hline & 180 & -9312 & -12030 & -14568 & -6183 & -7799 & -9307 & -4826 & -5969 & -7036 \\
\hline & 210 & -7307 & -8861 & -10311 & -4976 & -5899 & -6761 & -3961 & -4615 & -5225 \\
\hline \multirow[t]{3}{*}{ Non-irrigated } & 0 & -2046 & -2046 & -2046 & -1519 & -1519 & -1519 & -1292 & -1292 & -1292 \\
\hline & 60 & 995 & 218 & -507 & 122 & -340 & -771 & -242 & -569 & -874 \\
\hline & 120 & 1539 & -15 & -1465 & 368 & -555 & -1417 & -120 & -773 & -1383 \\
\hline \multirow[t]{3}{*}{ Sweetgum irrigated } & 0 & -8980 & -8980 & -8980 & -5795 & -5795 & -5795 & -4423 & -4423 & -4423 \\
\hline & 60 & -3224 & -3884 & -4499 & -2623 & -3012 & -3376 & -2346 & -2620 & -2875 \\
\hline & 120 & -3251 & -4570 & -5801 & -2682 & -3461 & -4188 & -2416 & -2964 & -3475 \\
\hline \multirow[t]{8}{*}{ Non-irrigated } & 0 & -1122 & -1122 & -1122 & -1003 & -1003 & -1003 & -949 & -949 & -949 \\
\hline & 20 & 1952 & 1732 & 1527 & 700 & 570 & 449 & 173 & 82 & -3 \\
\hline & 40 & 2297 & 1857 & 1447 & 878 & 618 & 376 & 281 & 98 & -72 \\
\hline & 60 & 2713 & 2054 & 1439 & 1096 & 707 & 343 & 416 & 142 & -114 \\
\hline & 80 & 2022 & 1143 & 322 & 695 & 176 & -309 & 139 & -226 & -567 \\
\hline & 100 & 2465 & 1367 & 341 & 928 & 279 & -326 & 283 & -173 & -599 \\
\hline & 120 & 2430 & 1111 & -120 & 894 & 115 & -612 & 250 & -298 & -809 \\
\hline & 140 & 1767 & 229 & -1207 & 509 & -400 & -1248 & -16 & -655 & -1252 \\
\hline
\end{tabular}

tant task is to identify $\mathrm{N}$ rate recommendations on the basis of regression designs results from the lower limit of the optimal confidence intervals, so that economically excessive $\mathrm{N}$ applications are avoided (Bachmaier, 2012). The uncertainty estimates also provides for comparisons among treatments, which, for example, here included testing differences between irrigation treatments and among various species. Furthermore, the Kolmogorov-Smirnov comparison allowed us to test for general differences between two trajectories, which in this case involved comparing between irrigation treatments. Although the confidence intervals for individual regression parameters and curve optima were too broad to discern most differences among treatments, the two-way Kolmogorov-Smirnov test confirmed visual evaluations suggest- ing important differences between primary and secondary irrigation. These various tests allowed us to evaluate hypotheses regarding optimum fertilization rates for various species growing with and without irrigation.

The secondary irrigation treatment included the minimum required (i.e., three $\mathrm{N}$ fertilization levels) to test for non-linearity of the response variable. The unknown coefficients $b_{i}$ of Eq. (2) are determined using least-squares estimates $b_{i}$. This requires at least three different $\mathrm{N}$ application rates; otherwise the estimates would not be unique. However, more than three treatment levels should be included to determine a thorough description of non-linear trajectories. If only three are included, each level has a large influence over the shape of the resulting curve when there is substantial er- 
ror among plots, as found in this study. For example, the intermediate $\mathrm{N}$ rate biomass value for the non-irrigated curve of ST66 drew the line to a sharp maximum at that point. Four or more $\mathrm{N}$ application rates would substantiate the finding observed. Additionally, the width of the confidence intervals would be reduced if the regression was based on more data, and hence the accuracy and reliability of the estimated optimal values can be improved by increasing the number of $\mathrm{N}$ application rates. Despite these shortcomings, the regression approach and demonstrated analyses provide important tools to evaluate effects among multiple levels of silvicultural treatments, and can be applied to forestry systems worldwide.

\section{Acknowledgements}

Thanks to the many project technicians and staff at the USDA Forest Service-Savannah River who made data collection possible. Dick Daniels (UGA Warnell School of Forestry and Natural Resources) significantly contributed to the design of this experiment, and the comments from two anonymous reviewers greatly improved this manuscript. Special thanks to John Blake (USDA Forest Service-Savannah River) and the Savannah River Ecology Laboratory (UGA) for project support, including use of equipment and facilities. Funding was provided by the Department of EnergySavannah River Operations Office through the U.S. Forest Service Savannah River and the Forest Service Southern Research Station under Interagency Agreement DE-IA09-00SR22188; Department of Energy Oak Ridge National Laboratory Interagency Agreement 00-IA-11330135-221; Southern Research Station Research Work Units 4103, 4104, 4154, 4155, 4505, and 4703; The Timber Company, Weyerhaeuser Company, Champion International, and Union Camp.

\section{References}

Allen, C.B., Will, R.E., Jacobson, M.A., 2005. Production efficiency and radiation use efficiency of four tree species receiving irrigation and fertilization. For. Sci. 51, 556-569.

Aravindhakshan, S.C., Epplin, F.M., Taliaferro, C.M., 2011. Switchgrass, bermudagrass, flaccidgrass, and lovegrass biomass yield response to nitrogen for single and double harvest. Biomass Bioenergy 35, 308-319.

Aubrey, D.P., Coyle, D.R., Coleman, M.D., 2012. Functional groups show distinct differences in nitrogen cycling during early stand development: implications for forest management. Plant Soil 351, 219-236.

Bachmaier, M., 2012. Sources of inaccuracy when estimating economically optimum N fertilizer rates. Agric. Sci. 3, 331-338.

Binkley, D., Reid, P., 1984. Long-term responses of stem growth and leaf area to thinning and fertilization in a Douglas-fir plantation. Can. J. For. Res. 14, 656660.

Blumenthal, J.M., Lyon, D.J., Stroup, W.W., 2003. Optimal plant population and nitrogen fertility for dryland corn in western Nebraska. Agron. J. 95, 878-883.

Borger, C.D.P., Walsh, M., Scott, J.K., Powles, S.B., 2007. Tumbleweeds in the Western Australian cropping system: seed dispersal characteristics of Salsola australis. Weed Res. 47, 406-414.

Brazee, R.J., 2001. The Faustmann formula: fundamental to forest economics 150 years after publication. For. Sci. 47, 441-442.

Brooks, J.R., Coulombe, R., 2009. Physiological responses to fertilization recorded in tree rings: isotopic lessons from a long-term fertilization trial. Ecol. Appl. 19, 1044-1060.

Casella, G., Berger, R.L., 2001. Statistical Inference, 2nd ed. Duxbury, Pacific Grove, CA, $660 \mathrm{p}$.

Coleman, M.D., Coyle, D.R., Blake, J., Britton, K., Buford, M., Campbell, R.G., Cox, J. Cregg, B., Daniels, D., Jacobson, M., Johnsen, K., McDonald, T., McLeod, K., Nelson, E., Robison, D., Rummer, R., Sanchez, F., Stanturf, J., Stokes, B., Trettin, C., Tuskan, J., Wright, L., Wullschleger, S., 2004. Production of Short-rotation Woody Crops Grown with a Range of Nutrient and Water Availability: Establishment Report and First-year Responses. Gen. Tech. Rep. SRS-72. Asheville, NC: U.S. Dept. Agric., For. Serv., South. Res. Stn., pp. 1-21.

Coleman, M.D., Tolsted, D., Nichols, T., Johnson, W.D., Ween, E.G., Houghtaling, T. 2006. Post-establishment fertilization of Minnesota hybrid poplar plantations. Biomass Bioenergy 30, 740-749.

Conover, W.J., 1999. Practical Nonparametric Statistics, Third Edition. John Wiley and Sons, New York, 584 p.
Cottingham, K.L., Lennon, J.T., Brown, B.L., 2005. Knowing when to draw the line: designing more informative ecological experiments. Front. Ecol. Environ. 3, 145-152.

Coyle, D.R., Coleman, M.D., 2005. Forest production responses to irrigation and fertilization are not explained by shifts in allocation. For. Ecol. Manage. 208, 137-152.

Coyle, D.R., Coleman, M.D., Aubrey, D.P., 2008. Above and belowground biomass accumulation, production, and distribution of sweetgum and loblolly pine grown with irrigation and fertilization. Can. J. For. Res. 38, 1335-1348.

Davis, A., Trettin, C., 2006. Sycamore and sweetgum plantation productivity on former agricultural land in South Carolina. Biomass Bioenergy 30, 769-777.

DeBell, D.S., Clendenen, G.W., Harrington, C.A., Zasada, J.C., 1996. Tree growth and stand development in short-rotation Populus plantings: 7-year results for two clones at three spacings. Biomass Bioenergy 11, 253-269.

Fisher, R.F., Garbett, W.S., 1980. Response of semimature slash and loblolly pine plantations to fertilization with nitrogen and phosphorus. Soil Sci. Soc. Am. J. 44, 850-854.

Fortier, J., Gagnon, D., Truax, B., Lambert, F., 2010. Biomass and volume yield after 6 years in multiclonal hybrid poplar riparian buffer strips. Biomass Bioenergy 34, 1028-1040.

Fox, T.R., Allen, H.L., Albaugh, T.J., Rubilar, R., Carlson, C.A., 2007. Tree nutrition and forest fertilization of pine plantations in the southern United States. South. J. Appl. For. 31, 5-11.

Gallagher, T., Shaffer, B., Rummer, B., 2006. An economic analysis of hardwood fiber production on dryland irrigated sties in the US Southeast. Biomass Bioenergy 30, 794-802.

Geyer, W.A., 2006. Biomass production in the Central Great Plains USA under various coppice regimes. Biomass Bioenergy 30, 778-783.

Henderson, D.E., Jose, S., 2010. Biomass production potential of three short rotation woody crop species under varying nitrogen and water availability. Agroforest. Syst. 80, 259-273.

Hirschberg, G., Lye, J.N., 2004. Inferences for the Extremum of Quadratic Regression Models. Working Paper, Department of Economics, University of Melbourne, $906 \mathrm{p}$.

Ibell, P.T., Xu, Z.H., Blumfield, T.J., 2010. Effects of weed control and fertilization on soil carbon an d nutrient pools in an exotic pine plantation of subtropical Australia. J. Soil Sediment 10, 1027-1038.

Ingestad, T., Ågren, G.I., 1991. The influence of plant nutrition on biomass allocation. Ecol. Appl. 1, 168-174

Jokela, E.J., Martin, T.A., Vogel, J.G., 2010. Twenty-five years of intensive forest management with southern pines: important lessons learned. J. For. 108, 338347.

Kimetu, J.M., Mugendi, D.N., Palm, C.A., Mutuo, P.K., Gachengo, C.N., Bationo, A., Nandwa, S., Kungu, J.B., 2004. Nitrogen fertilizer equivalencies of organic materials of differing quality and optimum combination with inorganic nitrogen source in Central Kenya. Nutr. Cycling Agroecosyst. 68, 127-135.

Kline, K.L., Coleman, M.D., 2010. Woody energy crops in the southeastern United States: two centuries of practitioner experience. Biomass Bioenergy 34, 16551666.

Kozlowski, T.T., Pallardy, S.G., 2002. Acclimation and adaptive responses of woody plants to environmental stresses. Bot. Rev. 68, 270-334.

Kramer, P.J., 1983. Water Relations of Plants. Academic Press, New York, NY, 489 p.

Kuha, J., Temple, J., 2003. Covariate measurement error in quadratic regression. Internat. Stat. Rev. 71, 131-150.

Lee, K.H., Jose, S., 2005. Nitrate leaching in cottonwood and loblolly pine biomass plantations along a nitrogen fertilization gradient. Agric. Ecosys. Environ. 105, 615-623.

Linder, S., 1989. Nutritional control of forest yield. In: Nutrition of Trees. The Marcus Wallenberg Foundation, Falun, Sweden, pp. 62-87.

Lockaby, B.G., Clawson, R.G., Baker, T., 1997. Response of three hardwood species to irrigation and fertilization on an upland site. South. J. Appl. For. 21, 123-129.

Lutz, R.P., 2001. Discounted cash flow methods. In: Handbook of Industrial Engineering, 3rd ed. Wiley \& Sons, Inc., New York, pp. 2231-2259.

Matsuzaki, S.S., Usio, N., Takamura, N., Washitani, I., 2009. Contrasting impacts of invasive engineers on freshwater ecosystems: an experiment and metaanalysis. Oecologia 158, 673-686.

Meason, D.F., Markewitz, D., Will, R.E., 2004. Annual fertilization and interspecific competition control: effects on in situ forest floor nitrogen fluxes of different aged Pinus taeda stands in southeast Georgia, USA. Can. J. For. Res. 34, 18021818.

Ngoze, S., Riha, S., Lehmann, J., Verchot, L., Kinyangi, J., Mbugua, D., Pell, A., 2008. Nutrient constraints to tropical agroecosystem productivity in long-term degrading soils. Global Change Biol. 14, 2810-2822.

Parresol, B.R., 1999. Assessing tree and stand biomass: a review with examples and critical comparisons. For. Sci. 45, 573-593.

Pearson, C.H., Halvorson, A.D., Moench, R.D., Hammon, R.W., 2010. Production of hybrid poplar under short-term, intensive culture in Western Colorado. Indust. Crops Prod. 31, 492-498.

Rogers, V.A., 1990. Soil Survey of Savannah River Plant area, parts of Aiken, Barnwell, and Allendale counties, South Carolina. USDA Soil Conservation Service, Washington DC.

Samuelson, L.J., 1998. Influence of intensive culture on leaf net photosynthesis and growth of sweetgum and loblolly pine seedlings. For. Sci. 44, 308-316.

Samuelson, L., Stokes, T., Cooksey, T., McLemore III, P., 2001. Production efficiency of loblolly pine and sweetgum in response to four years of intensive management. Tree Physiol. 21, 369-376. 
Schlesinger, W.H., Andrews, J.A., 2000. Soil respiration and the global carbon cycle. Biogeochemistry 48, 7-20.

Shan, J., Morris, L.A., Hendrick, R.L., 2001. The effects of management on soil and plant carbon sequestration in slash pine plantations. J. Appl. Ecol. 38, 932-941.

Siry, J.P. 2002. Timber-2: Intensive timber management practices. In: Wear, D.N. Greis, J.G. (Eds.), Southern Forest Resource Assessment, pp. 327-340. USDA For. Serv. Gen. Tech. Rep. SRS-53. 635 p.

Smethurst, P.J., 2010. Forest fertilization: trends in knowledge and practice compared to agriculture. Plant Soil 335, 83-100.

Smethurst, P.J., Baillie, C., Cherry, M., Holz, G., 2003. Fertilizer effects on LAI and growth of four Eucalyptus nitens plantations. For. Ecol. Manage. 176, 531-542.

Stape, J.L., Binkley, D., Jacob, W.S., Takahashi, E.N., 2006. A twin-plot approach to determine nutrient limitation and potential productivity in Eucalyptus plantations at landscape scales in Brazil. For. Ecol. Manage. 223, 358-362.

Straka, T.J., Bullard, S.H., 1996. Land expectation value calculation in timberland valuation. Apprasial J. 64, 399-405.

Sword Sayer, M.A., Goelz, J.C.G., Chambers, J.L., Tang, Z., Dean, T.J., Haywood, J.D., Leduc, D.J., 2004. Long-term trends in loblolly pine productivity and stand characteristics in response to thinning and fertilization in the West Gulf region. For. Ecol. Manage. 192, 71-96.

Van Miegroet, H., Norby, R.J., Tschaplinski, T.J., 1994. Nitrogen-fertilization strategies in a short-rotation sycamore plantation. For. Ecol. Manage. 64, 13-24.
Vogel, K.P., Bredja, J.J., Walters, D.T., Buxton, D.R., 2002. Switchgrass biomass production in the Midwest USA: harvest and nitrogen management. Agron. J. $94,413-420$.

Will, R.E., Wheeler, M.J., Markewitz, D., Jacobson, M.A., Shirley, A.M., 2002. II. Early loblolly pine stand response to tillage on the Piedmont and Upper Coastal Plain of Georgia: tree allometry, foliar nitrogen concentration, soil bulk density, soil moisture, and soil nitrogen status. South. J. Appl. For. 26, 190-196.

Will, R.E., Markewitz, D., Hendrick, R.L., Meason, D.F., Crocker, T.R., Borders, B.E. 2006. Nitrogen and phosphorus dynamics for a chronosequence of loblolly pine stands receiving fertilization and competition control. For. Ecol. Manage. 227, $155-168$.

Williams, T.M., Gresham, C.A., 2006. Biomass accumulation in rapidly growing loblolly pine and sweetgum. Biomass Bioenergy 30, 370-377.

Wood Resource Quarterly, 2012. Wood Resources International, Bothell, WA, USA $52 \mathrm{p}$.

Zalesny Jr., R.S., Hall, R.B., Zalesny, J.A., McMahon, B.G., Berguson, W.E., Stanosz, G.R. 2009. Biomass and genotype $\times$ environment interactions of Populus energy crops in the midwestern United States. BioEnergy Res. 2, 106-122.

Zhao, D., Kane, M., Borders, B.E., Harrison, M., Rheney, J.W., 2009. Site preparation and competing vegetation control affect loblolly pine long-term productivity in the southern Piedmont/Upper Coastal Plain of the United States. Ann. For. Sci. $66,705-713$. 